\title{
Ksiądz profesor Jerzy Bajda kapłan w środowisku rodzinnym
}

Nasze wystąpienie nie ma charakteru naukowego referatu. Są to refleksje i wspomnienia przekazywane na zasadzie świadectwa. Ufamy, że przybliżą one postać Księdza Profesora i w ten sposób pomogą lepiej zrozumieć jego nauczanie, którym niniejsza konferencja się zajmuje.

Oboje jesteśmy absolwentami łomiankowskich studiów nad rodziną, należymy do pierwszej generacji studentów tego kierunku. W początkowym okresie studia te miały niezwykły klimat ze względu na niewielką liczebność poszczególnych roczników, co sprzyjało budowaniu głębokich międzyosobowych relacji. Nawiązywaliśmy je to nie tylko w czasie zajęć, ale również poza nimi. Były więc wspólne wyjścia na koncerty, do kina, teatru, a również spotkania towarzyskie organizowane przy różnych okazjach. Ich nieodłącznym elementem był wspólny śpiew. Na te spotkania zapraszaliśmy Księdza Profesora Bajdę. A on chętnie z tych zaproszeń korzystał, gdyż był wielkim miłośnikiem wspólnego śpiewu. I tak budowała się szczególna więź łącząca profesora i jego studentów.

Ksiądz Bajda był człowiekiem niezwykle wrażliwym na potrzeby innych osób, natomiast niespecjalnie dbał o swoje. Oddelegowany z diecezji tarnowskiej do pracy naukowej w Warszawie, nie zadbał o to, by mieć jakieś stałe lokum. Mieszkał najpierw w konwikcie przy Akademii Teologii Katolickiej. Później przenosił się do mieszkań różnych znajomych, którzy mu je na jakiś 
czas (na przykład z powodu wyjazdu za granicę) udostępniali. Razem z kolegami pomagaliśmy Księdzu Profesorowi w tych przeprowadzkach. Cały czas, również po zakończeniu studiów, utrzymywaliśmy z nim bliskie relacje. Później gdy byliśmy już małżeństwem, często odwiedzał nas w Otwocku, gdzie mieszkaliśmy. Po pewnym czasie znów pojawiła się potrzeba znalezienia mieszkania dla księdza Bajdy. Kończyliśmy w tym czasie budowę naszego domu. I wtedy po modlitwie pojawiła się myśl, że można by na poddaszu naszego domu przygotować mieszkanie dla Księdza i zaprosić go do nas. Podzieliliśmy się z nim tym pomysłem. Odpowiedział na nasze zaproszenie pozytywnie i tak rozpoczął się okres blisko 23 lat naszego wspólnego zamieszkiwania.

Mogliśmy korzystać z tego niezwykłego daru, jakim była obecność kapłana w codziennym naszym życiu. Mamy pięcioro dzieci. Każde z nich było ochrzczone przez księdza Bajdę. Udzielał im pierwszych komunii świętych. Był celebransem na ślubach najstarszej trójki (warto wspomnieć, że wcześniej był również głównym celebransem na naszym ślubie). Mogliśmy wielokrotnie uczestniczyć w sprawowanych w naszym domu mszach świętych. Najczęściej działo się tak, gdy ktoś chorował. Spotykaliśmy się też wspólnie na wieczornej rodzinnej modlitwie. Każdego dnia ktoś inny był odpowiedzialny za prowadzenie tej modlitwy. Ksiądz umiał uszanować nawet bardzo proste formy proponowane przez nasze dzieci. Modlitwę zawsze kończyło kapłańskie błogosławieństwo i robione przez Księdza i przez nas na czołach dzieci „krzyżyki”. My takie „krzyżyki” otrzymywaliśmy też od Księdza. Wspomnieć należy również o licznych rozmowach na tematy duchowe oraz o posłudze Księdza jako naszego stałego spowiednika.

Ubogacał on również rodzinne świętowanie uroczystości i świąt kościelnych, naszych jubileuszy, imienin, urodzin. Nieodłącznym elementem tego świętowania był wspólny śpiew. W okresie Bożego Narodzenia śpiewaliśmy oczywiście kolędy. W Wielkim Poście tradycją stało się rodzinne śpiewanie Gorzkich żali. Były też wieczory patriotyczne z okazji rocznicy odzyskania niepodległości.

Ksiądz miał na poddaszu swój pokój i łazienkę, na posiłki schodził do nas na dół. Staraliśmy się, aby z całą rodziną spotykać się na wspólnych niedzielnych posiłkach. Były one okazją do rozmów na temat różnych przeżywanych w rodzinie wydarzeń. Rozmawialiśmy również o tym, co dzieje się na świecie, w Kościele. Były też dyskusje i rozmowy na tematy teologiczne i filozoficzne. 
Ksiądz był wielkim pasjonatem aktywnej rekreacji. Zjeździł na rowerze i przemierzył pieszo chyba wszystkie szlaki turystyczne, których w Otwocku i w jego okolicach jest wiele. Zimą korzystał z nart biegowych. Były też wspólne wyprawy, zwłaszcza w góry, które bardzo lubił.

Wraz z upływem czasu te aktywności trzeba było redukować. Pojawiły się kłopoty zdrowotne. Udało się zaleczyć białaczkę, ale trzeba było wstawić rozrusznik serca. Później okazało się, że pojawiły się też nowotworowe zmiany w prostacie. Choroba postępowała dość szybko. Zaczęły się wizyty w przychodniach i gabinetach lekarskich. Pokora, na którą w postawie Księdza wiele osób zwraca uwagę, uwidaczniała się zwłaszcza wtedy w czasie licznych badań i lekarskich konsultacji.

Po pewnym czasie Ksiądz oświadczył nam, że nie może być dłużej ciężarem dla naszej rodziny, że podjął decyzję o powrocie do Tarnowa, do swojej rodzinnej diecezji, do domu księży emerytów. Próbowaliśmy nakłonić go do zmiany tej decyzji. Podkreślaliśmy, że tak jak w rodzinie chcemy mu dalej pomagać. Stwierdził, że jest to decyzja przemodlona i nieodwołalna. Była jesień 2011 roku. Uprosiliśmy go, abyśmy mogli jeszcze wspólnie spędzić Święta Bożego Narodzenia i bezpośrednio po nich wraz z przyjaciółmi odwieźliśmy go do Tarnowa. Tam wielokrotnie odwiedzaliśmy go. Byliśmy też w stałym kontakcie przez Skype’a. W czerwcu 2012 roku przyjechał jeszcze do nas, potem razem pojechaliśmy do Tarnowa.

8 września 2011 r., w uroczystość Narodzenia Najświętszej Maryi Panny napisał Ksiądz słabnąca ręką (co widać po charakterze pisma) swój testament. Zakończył go w ten sposób:

„Wyrażam serdeczną wdzięczność wszystkim, którzy okazywali mi troskę, opiekę, zarazem przepraszam wszystkich, wobec których w czymś zawiniłem. Pragnę umierać ze słowami modlitwy na ustach: Boże kocham Cię, Jezu ufam Tobie, ukryty w ramionach Matki Niepokalanej”.

Trzy miesiące później zmarł. 
